\title{
PENYELESAIAN SENGKETA PEMBATALAN PERNIKAHAN KARENA ADANYA PENIPUAN STATUS ISTRI
}

\author{
Amelia Haryanti \\ Fakultas Keguruan dan Ilmu Pendidikan, Universitas Pamulang \\ dosen00811@unpam.ac.id
}

\begin{abstract}
Abstrak
Artikel ini membahas mengenai proses penyelesaian sengketa pembatalan perkawinan karena adanya penipuan mengenai status istri. Metode yang di gunakan adalah metode Yuridis Normatif yang bertujuan untuk mendiskripsikan proses penyelesaian sengketa pembatalan perkawinan karena adanya penipuan mengenai status istri. Data primer penelitian ini adalah putusan Pengadilan Agama Makasar Nomor 1098/Pdt.G/2011/PA.Mks. Data sekunder adalah bahan yang memberikan penjelasan mengenai bahan hukum primer, pendapat pakar hukum, dan jurnal-jurnal ilmiah yang ada hubungannya dengan perkara permohonan pembatalan perkawinan karena adanya penipuan mengenai status istri. Hasil pengamatan putusan Pengadilan Agama Makasar Nomor 1098/Pdt.G/2011/PA.Mks. adalah dalam menentukan pembuktian hakim mempertimbangkan alat bukti yang Pemohon ajukan di persidangan. Sedangkan dalam menentukan putusan hakim menjatuhkan putusan verstek dengan mengabulkan permohonan Pemohon. Dan sebagai akibat hukum karena pembatalan perkawinan adalah perkawinan antara Pemohon dan Termohon dianggap tidak pernah ada, dan putusan pembatalan perkawinan tersebut berlaku surut terhadap anak luar kawin.
\end{abstract}

Kata-kata kunci: pembatalan perkawinan, penipuan, status istri

\footnotetext{
Jurnal Pendidikan Kewarganegaraan

Journal of Civics and Education Studies

The journal is published by Department of Civic Education

Faculty of Teacher Training and Education

Universitas Pamulang - Indonesia
}

Copyright $\odot 2017 \mid$ ISSN: 2302-0865 


\section{PENDAHULUAN}

Manusia adalah makhluk sosial (zoon politicon) yang selalu mengadakan hubungan satu sama lain. Dalam hubungan interaksi tersebut tidak jarang terjadi suatu konflik atau sengketa, karena adanya pihak yang merasa dirugikan yang membutuhkan perlindungan hukum atas hak-haknya dan mengajukan tuntutan kepada pihak yang dianggap merugikannya. Di dalam sengketa timbul dua pihak yang berlawanan, yaitu pihak yang satu sebagai pihak Penggugat (eiser) dan pihak yang lainnya sebagai pihak Tergugat (gedagde). Mereka ini merupakan pihak materiil, karena mereka mempunyai kepentingan langsung di dalam perkara yang bersangkutan dan sekaligus juga merupakan pihak formil, karena mereka yang beracara di muka pengadilan yang bertindak untuk kepentingan dan atas namanya sendiri (Soeroso, 2011: 15).

Dalam suatu perkara yang memberikan putusan adalah tugas hakim. Yang dimaksud dengan putusan hakim adalah putusan akhir dari suatu pemeriksaan persidangan di pengadilan dalam suatu perkara.

Putusan akhir dalam suatu sengketa yang diputuskan oleh hakim yang memeriksa dalam persidangan umumnya mengandung sanksi berupa hukuman terhadap pihak yang dikalahkan dalam suatu persidangan di pengadilan. Dalam hukum acara perdata, hukumannya berupa pemenuhan prestasi dan atau pemberian ganti rugi kepada pihak yang telah dirugikan atau yang dimenangkan dalam persidangan pengadilan dalam suatu sengketa.

Dalam persidangan hukum acara perdata, hakim yang memeriksa suatu perkara sebelum memberikan keputusan akhir untuk mendapatkan bukti-bukti yang akurat dan atau untuk mempersiapkan putusan akhir umumnya dapat memberikan putusan preparatoir, putusan interlocutoir, putusan insidentil dan putusan provisionil, yang mana dalam hukum acara perdata kesemua putusan tersebut adalah sebagai putusan sela karena putusan ini sifatnya hanya sementara dengan maksud dan tujuan untuk memperlancar jalannya persidangan (Sarwono, 2012: 211).

Selain itu, juga terdapat jenis-jenis putusan hakim dalam hukum acara perdata yang lainnya yaitu putusan declaratoir, putusan constitutief, dan putusan condemnatoir. Putusan declaratoir adalah putusan yang hanya menegaskan atau menyatakan suatu keadaan hukum semata-mata, misalnya putusan tentang keabsahan anak angkat menurut hukum, putusan ahli waris yang sah, putusan pemilik atas suatu benda yang sah dan lain sebagainya. Putusan constitutief adalah putusan yang dapat meniadakan suatu keadaan hukum atau menimbulkan suatu keadaan hukum yang baru, misalnya putusan tentang perceraian, putusan yang menyatakan bahwa seseorang jatuh pailit, putusan tidak berwenangnya pengadilan menangani suatu perkara dan lain sebagainya. Putusan condemnatoir adalah putusan yang bersifat menghukum pihak yang dikalahkan dalam persidangan untuk memenuhi prestasi. Pada umumnya 
putusan ini terjadi disebabkan oleh karena dalam hubungan perikatan antara penggugat dan tergugat yang bersumber pada perjanjian atau undang-undang telah terjadi wanprestasi dan perkaranya diselesaikan di pengadilan (Sarwono, 2012: 212).

Kekuasaan peradilan dalam kaitannya dengan hukum acara perdata, biasanya menyangkut dua hal, yaitu tentang kekuasaan relatif dan kekuasaan absolut. Kekuasaan relatif diartikan sebagai kekuasaan pengadilan yang satu jenis dan satu tingkatan, dalam perbedaannya dengan kekuasaan pengadilan yang sama jenis dan sama tingkatan lainnya (Rasyid, 2005: 25). Kekuasaan absolut artinya kekuasaan pengadilan yang berhubungan dengan jenis perkara atau jenis pengadilan atau tingkatan pengadilan, dalam perbedannya dengan jenis perkara atau jenis pengadilan atau tingkatan pengadilan lainnya. Misalnya Pengadilan Agama berkuasa atas perkara perkawinan bagi yang beragama Islam sedangkan bagi yang beragama lain menjadi kekuasaan Peradilan Umum (Rasyid, 2005: 27).

Berbicara tentang perkawinan, perkawinan merupakan suatu hal yang penting dalam realita kehidupan umat manusia. Dengan adanya perkawinan rumah tangga dapat ditegakkan dan dibina sesuai dengan norma agama dan tata kehidupan masyarakat (Manan, 2008: 1).

Perkawinan dianggap sebagai sesuatu yang sakral karena perkawinan memiliki nilai-nilai spiritual, sehingga perkawinan harus dilaksanakan dengan rangkaian upacara yang bersifat religius dan dilakukan menurut hukum masing- masing agama dan kepercayaan dari para pihak yang melangsungkan perkawinan. Hal ini seperti yang dinyatakan dalam Pasal 2 ayat (1) Undang-Undang Nomor 1 Tahun 1974 tentang Perkawinan, yaitu perkawinan adalah sah, apabila dilakukan menurut hukum masing-masing agamanya dan kepercayaannya itu.

Dalam hukum Islam perkawinan sah apabila telah dilakukan sesuai dengan Hukum Islam dan telah memenuhi syaratsyarat yang telah ditentukan dalam Undang-Undang Perkawinan.Jadi perkawinan menjadi batal apabila dilangsungkan tanpa memenuhi syarat dan rukun yang telah ditentukan dalam Undang-Undang Nomor 1 Tahun 1974 jo Kompilasi Hukum Islam.

Undang-Undang Nomor 1 Tahun 1974 peraturannya bersifat umum, sedangkan Kompilasi Hukum Islam merupakan peraturan yang bersifat khusus, karena hanya diperuntukkan bagi masyarakat Indonesia yang beragama Islam. Disamping itu Kompilasi Hukum Islam juga dijadikan pegangan bagi para Hakim Pengadilan Agama seluruh Indonesia dalam melaksanakan tugasnya dalam menyelesaikan perkara yang berhubungan dengan perkawinan, kewarisan dan perwakafan.

Dalam agama, perkawinan merupakan suatu lembaga yang suci.Upacara perkawinan adalah upacara yang suci, yang kedua pihak dihubungkan menjadi pasangan suami istri atau saling meminta menjadi pasangan hidupnya dengan mempergunakan nama Allah. Penyelenggaraan perkawinan di beberapa komunitas masyarakat biasanya tidak 
menghiraukan kehendak sebenarnya dari calon yang akan kawin, misalnya calon mempelai pria atau wanita baru mengetahui dengan siapa mereka akan dikawinkan pada saat perkawinan dilangsungkan. Ada pula kasus, perkawinan telah berlangsung sesuai dengan kehendak yang melangsungkan perkawinan, tetapi bertentangan dengan kehendak pihak lain, misalnya pada saat telah melangsungkan perkawinan baru diketahui bahwa keduanya ternyata memiliki hubungan keluarga atau ternyata baru diketahui bahwa mempelai pria atau wanita masih memiliki pasangan (suami/istri).

\section{METODE PENELITIAN}

Dalam memperoleh bahan dan informasi yang dibutuhkan dalam penelitian ini, maka penelitian menggunakan pendekatan undang-undang (statute uproach), dengan jenis bahan hukum primer dan skunder. Bahan hukum primer berupa peraturan perundang-undangan, catatan-catatan resmi atau risalah sidang perubahan UUD 1945, sedangkan bahan hukum skunder terdiri dari buku, majalah, media internet, kamus hukum, jurnal-jurnal, dan pendapat-pendapat para ahli yang berhubungan dengan penelitian ini. Dengan menggunakan Statute uproach, penulis akan menganalisa bahan hukum yang diperoleh, kemudian menjelaskan objek penelitian yang didapat berdasarkan kualitatif bahan, sehingga gambaran jelas tentang substansi materi yang akan dibahas dalam penelitian ini lebih akurat.

\section{HASIL DAN PEMBAHASAN}

\section{Tinjauan Umum Tentang Perkawinan}

Perkawinan yang dalam istilah agama disebut Nikah ialah melakukan suatu aqad atau perjanjian untuk mengikatkan diri antara seorang laki-laki dan wanita untuk menghalalkan hubungan kelamin antara kedua belah pihak, dengan dasar sukarela dan keridhoan kedua belah pihak untuk mewujudkan suatu kebahagiaan hidup berkeluarga yang diliputi rasa kasih sayang dan ketentraman dengan cara-cara yang diridhoi oleh Allah.

Mengenaipengertian perkawinan ini banyak pendapat yang berbeda. Perbedaan itu hanya terdapat pada keinginan para perumus untuk memasukkan unsur-unsur yang sebanyak-banyaknya dalam perumusan pengertian perkawinan di satu pihak dan pembatasan banyaknya unsur di dalam perumusan pengertian perkawinan di pihak yang lain. Mereka membatasi banyaknya unsur yang masuk dalam rumusan pengertian perkawinan dan menjelaskan unsur-unsur lain dalam tujuan perkawinan.

Walaupun ada perbedaan pendapat tentang perumusan pengertian perkawinan, tetapi dari semua rumusan yang dikemukakan ada satu unsur yang merupakan kesamaan dari seluruh pendapat, yaitu bahwa nikah merupakan suatu perjanjian perikatan antara seorang laki-laki dan seorang wanita. Perjanjian dalam nikah merupakan perjanjian suci untuk membentuk keluarga antara seorang laki-laki dan seorang wanita.Kata suci dilihat dari segi keagamaannya dari suatu perkawinan (Soemiyati, 2007: 8). 
Hukum perkawinan sebagai bagian dari hukum perdata ialah peraturanperaturan hukum yang mengatur perbuatan-perbuatan hukum serta akibatakibatnya antara dua pihak, yaitu seorang laki-laki dan seorang wanita dengan maksud hidup bersama untuk waktu yang lama menurut peraturan-peraturan yang ditetapkan dalam undang-undang. Kebanyakan isi peraturan mengenai pergaulan hidup suami istri diatur dalam norma-norma keagamaan, kesusilaan, atau kesopanan.

Hukum Perkawinan dibagi menjadi 2 bagian, yaitu: 1) Hukum Perkawinan, yaitu keseluruhan peraturan-peraturan yang berhubungan dengan suatu perkawinan; misalnya, hak dan kewajiban suami istri; dan 2) Hukum Kekayaan dalam Perkawinan yaitu keseluruhan peraturan hukum yang berhubungan dengan harta kekayaan suami istri di dalam perkawinan. Misalnya tentang harta bawaan masing-masing sebelum menikah (Tutik, 2008: 97).

Di Indonesia pelaksanaan Hukum Perkawinan masih pluralistis. Artinya di Indonesia berlaku tiga macam sistem hukum perkawinan, yaitu: 1) Hukum Perkawinan menurut Hukum Perdata Barat (BW), diperuntukkan bagi WNI keturunan asing atau yang beragama Kristen; 2) Hukum Perkawinan menurut Hukum Islam, diperuntukkan bagi WNI atau pribumi yang beragama Islam; 3) Hukum Perkawinan menurut Hukum Adat, diperuntukkan bagi masyarakat pribumi yang masih memegang teguh hukum adat.
Namun demikian, pada dasarnya Hukum Perkawinan bagi masyarakat asli yang beragama Islam kebanyakan merupakan perpaduan antara Hukum Islam dan Hukum Adat.Sedangkan Hukum Perkawinan BW diperuntukkan bagi WNI keturunan asing atau yang beragama Kristen, khususnya kalangan Tionghoa keturunan (Tutik, 2008: 97).

\section{Pembatalan Perkawinan}

Pembatalan perkawinan atau yang dalam bahasa Arab fasakh. Fasakh berasal dari bahasa Arab dari akar kata fa-sa-kha yang secara etimologiberarti membatalkan. Bila dihubungkan kata ini dengan perkawinan berarti membatalkan perkawinan atau merusak perkawinan. Dalam arti terminologis ditemukan beberapa rumusan yang hampir bersamaan maksudnya, di antaranya yang terdapat dalam KBBI. Pembatalan ikatan pernikahan oleh Pengadilan Agama berdasarkan tuntutan isteri atau suami yang dapat dibenarkan Pengadilan Agama atau karena pernikahan yang telah terlanjur menyalahi hukum pernikahan (Syarifuddin, 2011: 242).

Putusnya perkawinan atau disebut juga dengan perceraian ada yang terjadi atas inisiatif dari suami,yang disebut thalaq, ada yang merupakan inisiatif dari isteri dengan cara mengajukan ganti rugi yang disebut khulu'. Fasakh pada dasarnya terjadi atas inisiatif pihak ketiga, yaitu hakim setelah hakim mengetahui bahwa perkawinan itu tidak dapat dilanjutkan, baik karena pada perkawinan yang telah berlangsung ternyata terdapat kesalahan, 
seperti tidak memenuhi persyaratan yang ditentukan maupun dari diri suami atau isteri terdapat kekurangan yang tidak mungkin dipertahankan untuk kelangsungan perkawinan itu. (Syarifuddin, 2011: 243) .

Dasar hukum pembatalan perkawinan diatur dalam Pasal 37 PP Nomor 9 Tahun 1975 tentang Pelaksanaan UndangUndang Nomor 1 Tahun 1974 yaitu batalnya perkawinan hanya dapat diputuskan oleh Pengadilan. Dalam membicarakan jenis perkawinan yang dapat dibatalkan, Kompilasi Hukum Islam lebih sistematis daripada Undang-undang Nomor 1 Tahun 1974 Tentang Perkawinan dalam memuat masalah pembatalan nikah. Sementara pengertian tentang pembatalan nikah dikaitkan dengan nikah fasid dan nikah bathil.Nikah fasid yaitu jika tidak terpenuhinya salah satu syarat nikah dalam syariat Islam, sedangkan nikah bathil adalah jika perkawinan tidak memenuhi rukun nikah.

\section{Alasan-alasan Batalnya Perkawinan}

Terjadinya fasakh dapat secara garis besar dibagi ke dalam dua sebab, yaitu:

Pertama: Perkawinan yang sebelumnya telah berlangsung, ternyata kemudian tidak memenuhi persyaratan yang ditentukan, baik tentang rukun, maupun syaratnya atau pada perkawinan tersebut terdapat halangan yang tidak membenarkan terjadinya perkawinan. Bentuk seperti ini yang dalam kitab fiqh disebut fasakh.

Kedua: fasakh yang terjadi karena ada diri suami atau isteri terdapat sesuatu yang menyebabkan perkawinan tidak mungkin dilanjutkan, karena jika dilanjutkan akan menyebabkan kerusakan pada suami atau isteri atau keduanya sekaligus. Fasakh dalam bentuk ini dalam fiqh disebut dengan khiyar fasakh. (Syarifuddin, 2011: 243).

\section{Akibat Hukum Pembatalan Perkawinan}

Perkawinan suami istri yang dibatalkan akan mengakibatkan keduanya kembali seperti keadaan semula atau diantara keduanya seolah-olah tidak pernah melangsungkan perkawinan. Terkait dengan akibat hukum pembatalan perkawinan, dengan adanya putusan pengadilan yang membatalkan perkawinan maka perkawinan yang telah terjadi dianggap tidak pernah ada.Sebagaimana tercantum dalam Pasal 28 ayat (1) Undang-undang Perkawinan menentukan batalnya suatu perkawinan dihitung sejak aat berlangsungnya perkawinan.

Akibat hukum yang ditimbulkan karena adanya pembatalan perkawinan diatur dalam Pasal 28 ayat (2) UU No. 1 Tahun 1974, Pasal 75 dan Pasal 76 KHI yang mempunyai rumusan yang berbeda. Pasal 28 ayat (2) UU Perkawinan menyebutkan bahwa putusan tidak berlaku surut terhadap:

\section{1) Terhadap anak yang dilahirkan} dari perkawinan tersebut

Selanjutnya permasalahan yang berkenaan dengan akibat hukum terhadap pembatalan perkawinan di muat dalam Pasal 28 ayat (2), sebagai berikut: Keputusan tidak berlaku surut terhadap (1) Anak-anak yang dilahirkan dari perkawinan tersebut; (2) Suami atau isteri 
yang bertindak dengan iktikad baik, kecuali terhadap harta bersama, bila pembatalan perkawinan didasarkan atas adanya perkawinan lain yang lebih dahulu; (3) Orang-orang ketiga lainnya tidak termasuk dalam a dan b sepanjang mereka memperoleh hak-hak dengan iktikad baik sebelum keputusan tentang pembatalan mempunyai kekuatan hukum tetap.

Anak-anak yang dilahirkan dalam perkawinan yang telah dibatalkan tidak berlaku surut, sehingga dengan demikian anak-anak ini dianggap sah. Menurut UU No. 1 Tahun 1974 anak-anak yang dilahirkan itu mempunyai status hukum yang jelas sebagai anak yang sah dari kedua orang tuanya yang perkawinannya dibatalkan dan sepatutnya mendapatkan perlindungan hukum. Sebagai konsekuensi dari diakuinya anak itu sebagai anak yang sah bagi ayahnya, maka ia berhak mewarisi harta ayah kandungnya tersebut.

Pasal 42 Undang-Undang Nomor 1 Tahun 1974 menyatakan bahwa anak yang sah adalah anak yang dilahirkan dalam atau sebagai akibat perkawinan yang sah.Akibat yang berhubungan dengan anak, kedudukan anak yang perkawinan orang tuanya dibatalkan adalah sebagai anak yang sah dari kedua orang tuanya yang perkawinannya dibatalkan. Jadi, bagi anak-anak yang lahir dari perkawinan yang dibatalkan dapat mewarisi dari ayahnya maupun ibunya dan juga anak itu mempunyai hubungan kekeluargaan dengan keluarga si ayah ataupun ibu.

Akibat batalnya perkawinan dalam Kompilasi Hukum Islam diatur dalam
Pasal 75 dan Pasal 76. Dan Pasal 75 yang menyebutkan bahawa, putusan pembatalan perkawinan tidak berlaku surut terhadap perkawinan yang batal karena salah satu dari suami atau isteri murtad dan Anak-anak yang dilahirkan dari perkawinan, sedangkan Pasal 76 Kompilasi Hukum Islam menyebutkan bahwa batalnya suatu perkawinan tidak akan memutuskan hubungan hukum antara anak dengan orang tuanya.

\section{2) Terhadap Harta Bersama dan}

\section{Harta Bawaan}

a. Pembahasan mengenai harta yang ada pada dan sebelum perkawinan serta setelah pembatalan perkawinan merupakan masalah yang perlu mendapat pemahaman, karena hal ini menyangkut perlindungan hak dan kewajiban para pihak. Dilihat dari asal-usul harta suami istri menurut (Thalib, 1974:83-84) dapat digolongkan pada tiga golongan yaitu: Harta masing-masing suami isteri yang telah dimilikinya sebelum perkawinan baik berasal dari warisan, hibah atau usaha mereka sendirisendiri atau dapat disebut harta bawaan.

b. Harta masing-masing suami isteri yang dimilikinya sesudah mereka berada dalam hubungan perkawinan, tetapi diperolehnya bukan dari usaha mereka baik seorang-seorang atau bersama-sama, tetapi merupakan hibah, wasiat atau warisan untuk masing-masing.

c. Harta yang diperoleh sesudah mereka berada dalam hubungan perkawinan 
atas usaha mereka berdua atau usaha salah seorang mereka atau disebut harta pencarian.

Pada dasarnya harta suami dan harta istri terpisah, baik harta bawaanya masing-masing atau harta yang diperoleh oleh salah seorang suami isteri atas usahanya sendiri-sendiri maupun harta hibah yang diperoleh oleh salah seorang mereka karena hadiah atau hibah atau warisan sesudah mereka terikat dalam hubungan perkawinan. Adanya harta bersama tidak menutup kemungkinan adanya harta milik masing-masing suami dan isteri.Harta isteri tetap menjadi hak isteri dan dikuasai penuh olehnya, demikian juga harta suami tetap menjadi hak suami dan dikuasai penuh olehnya.

Menurut Undang-undang No. 1 Tahun 1974 mengenai harta bersama, suami atau isteri dapat bertindak atas persetujuan kedua belah pihak.Sedangkan mengenai harta bawaan masing-masing suami isteri mempunyai hak sepenuhnya untuk melakukan perbuatan hukum mengenai harta bendanya.Sedangkan dalam Kompilasi Hukum Islam Pasal 85 menggariskan bahwa pada dasarnya tidak ada percampuran antara harta suami dan harta isteri karena perkawinan, adanya harta bersama tidak menutup kemungkinan adanya harta milik masingmasing suami dan isteri. Harta isteri tetap menjadi hak isteri dan dikuasai penuh olehnya, demikian juga harta suami tetap menjadi hak suami dan dikuasai penuh olehnya.

Harta bawaan dari masing-masing suami dan isteri dan harta yang diperoleh masing-masing sebagai hadiah atau warisan adalah dibawah penguasaan masing-masing, sepanjang para pihak tidak menentukan lain dalam perjanjian perkawinan. Suami dan isteri mempunyai hak sepenuhnya untuk melakukan perbuatan hukum atas harta masingmasing berupa hibah, hadiah, sedekah atau lainnya.

Bagi harta kekayaan bersama (gonogini) merupakan harta bersama yang menjadi milik bersama, hanya saja tidak boleh merugikan pihak yang beritikad baik, bagaimanapun juga pihak yang beritikad baik harus diuntungkan, bahkan bagi pihak yang beritikad buruk harus menanggung segala kerugian-kerugian termasuk bunga-bunga harus ditanggung.

\section{3) Terhadap Pihak Ketiga}

Orang-orang ketiga lainnya tidak termasuk dalam poin a dan b sepanjang mereka memperoleh hak-hak dengan iktikad baik sebelum putusan tentang pembatalan mempunyai kekuatan hukum tetap.Terhadap pihak ketiga yang beritikad baik pembatalan perkawinan tidak mempunyai akibat hukum yang berlaku surut, jadi segala perbuatan perdata atau perikatan yang diperbuat suami isteri sebelum pembatalan perkawinan tetap berlaku, dan ini harusdilaksanakan oleh suami isteri tersebut, sehingga pihak ketiga yang beritikad baik tidak dirugikan.

Sebagai contoh: apabila Tergugat I dan Tergugat II membeli rumah yang dibayar secara kredit kepada pihak ketiga, sedangkan perjanjian pembayaran harus diangsur 30x dan dibayar bulanan, tetapi baru mendapat $5 \mathrm{x}$ angsuran sehingga 
masih kurang 15 angsuran sedangkan pernikahan mereka telah dibatalkan,walaupun begitu pembayaran harus tetap dilunasi karena itu merupakan hak bagi pihak ketiga.

Jadi orang-orang seperti mereka dilindungi undang-undang dalam hal terjadinya pembatalan perkawinan, dan putusan pengadilan tidak berlaku surut, maka pembatalan perkawinan dianggap berlaku setelah urusannya selesai. Pasal 28 ayat (2) tersebut merupakan pengecualian dari ketentuan sebelumnya.

\section{Pertimbangan Hakim dalam Memutus Perkara Pembatalan Pernikahan}

Penelitian hukum ini bertujuan untuk mengkaji: 1) pertimbangan hakim dalam memutus Perkara Nomor : 0864/Pdt.G/2009/PA; dan 2) dampak dan akibat hukum dari pembatalan perkawinan terhadap hubungan suami isteri, kedudukan anak, dan harta bersama.

Pengamatan tentang Tinjauan Yuridis Terhadap Pembatalan Perkawinan (Studi Kasus Putusan Hakim Pengadilan Agama Nomor : 0864/Pdt.G/2009/PA) adalah merupakan Penelitian hukum yuridis normatif yaitu metode penelitian hukum yang dilakukan dengan cara meneliti bahan pustaka atau bahan sekunder belaka.

Pengamatan dilakukan melalui analisa terhadap pasal-pasal dalam peraturan perundang-undangan yang mengatur tentang topik penelitian, hal ini dilakukan untuk mendapatkan data primer berkenaan dengan hal-hal yang ada di lapangan, serta bahan-bahan yang menyangkut materi-materi yang berhubungan dengan topik penelitian sebagai data sekunder.

Hasil pengamatan menunjukan:

a. Dasar pertimbangan Hakim untuk menerima dan memutuskan perkara pembatalan perkawinan, dalam hal ini terhadap Putusan Perkara Nomor: 0864/Pdt.G/PA. di Pengadilam Agama, karena tidak memenuhi salah satu persyaratan perkawinan yaitu tidak terikat perkawinan dengan orang lain. Tanpa persetujuan dari Pemohon yang masih berstatus istri yang sah, Termohon I telah melangsungkan perkawinan dengan Termohon II.Selain itu Termohon I juga tidak mengajukan permohonan kepada pengadilan untuk melangsungkan pernikahannya yang kedua itu.

b. Pembatalan perkawinan yang terjadi membawa akibat hukum atas beberapa hal, yaitu: terhadap hubungan suami-isteri, terhadap kedudukan anak dan terhadap harta bersama. Hubungan suami isteri setelah dikeluarkannya putusan pembatalan perkawinan kembali ke keadaan semula dan dianggap tidak pernah terjadi, tetapi tidak demikian dengan status si anak, yang tetap merupakan anak sah yang lahir dari perkawinan itu, sehingga orang tua wajib menafkahi si anak terutama si ayah yang harus memenuhi hak alimentasi anaknya. Terhadap harta bersama, 
harta benda yang merupakan harta bersama dalam perkawinan, apabila terjadi pembatalan perkawinan, maka harta itu akan kembali pada keadaan seperti belum terjadinya perkawinan.

Contoh study kasus mengenai pertimbangan hakim di Makasar.

\section{Pertimbangan Hakim dalam Putusan Nomor 1098/Pdt.G/2011/PA.Mks}

Berdasarkan hasil Putusan Pengadilan Agama Makassar Nomor 1098/Pdt.G/2011/PA.Mks terdapat adanya pemalsuan identitas dan tidak adanya izin poligami dalam perkawinan antara Tergugat I dengan Tergugat II.Status dari perkawinan ini setidaktidaknya batal demi hukum karena tidak adanya izin dari yang berhak.

Dari putusan tersebut tersirat pertimbangan hakim dengan dalil/alasan pokok yang mendasari gugatan tersbut adalah pihak tergugat melangsungkan perkawinan tanpa sepengetahuan dan seizin dari penggugat selaku istri yang sah dari perkawinan sebelumnya.

Dalam pertimbangan ini gugatan penggugat didasari oleh kewenangannya untuk memberikan izin kepada Tergugat I ternyata dipalsukan dimana tergugat I memberikan surat keterangan palsu yang menyatakan bahwa penggugat telah meninggal dunia, dimana seolah-olah untuk mengelabui Imam Kecamatan untuk menikahkan Tergugat I dengan Tergugat II padahal dalam kenyataan Penggugat (istri I tergugat) masih hidup.

Pertimbangan lain yaitu bahwa Tergugat I dengan Tergugat II juga turut tergugat dalam hal ini ternyata tidak pernah hadir dalam persidangan meskipun telah dipanggil secara resmi dan patut serta ketidakhadiran para tergugat tersebut tidak disebabkan oleh halangan yang sah, maka tergugat harus dinyatakan tidak hadir dan gugatan penggugat dapat diputus dengan Verstek sesuai Pasal 149 (1) Rbg.

Dalam pertimbangan ini Tergugat I sulit untuk melakukan pembelaan dan mempertahankan perkawinannya sehingga tidak menghadiri persidangan yang dilaksanakan. Selanjutnya terungkap juga bahwa sebelum perkawinan tersebut berlangsung Tergugat II tidak mengetahui bahwa Tergugat I masih terikat perkawinan yang sah sebelumnya dan terdapat unsur pidana karena adanya pemalsuan identitas tergugat I. oleh karena itu, secara hukum perkawinan ini batal demi hukum.

Pertimbangan hakim lainnya bahwa penggugat mendalilkan pada pokoknya tergugat I telah menikah dengan tergugat II tanpa izin dari penggugat dan Pengadilan Agama sementara tergugat I adalah Pegawai Negeri Sipil sehingga penggugat mohon pembatalan atas perkawinan tergugat I dan tergugat II, yang dilangsungkan di Kecamatan Tamalate, Kota Makassar, pada tanggal 18 Mei 2011. Dalam hal ini, bahwa berdasarkan ketentuan Pasal 149 (1) Rbg, yaitu dalam hal putusan dijatuhkan tanpa hadirnya tergugat, maka gugatan penggugat dapat dikabulkan dengan syarat gugatan penggugat 64 tersebut beralasan hukum, dan atas syarat itu pula maka majelis hakim membebankan kepada 
penggugat untuk membuktikan dalil-dalil gugatannya.

Selanjutnya penggugat juga mengajukan alat bukti surat berupa Kutipan Akta Nikah penggugat dengan tergugat I yang menunjukkan dan membuktikan bahwa antara penggugat dengan tergugat I telah terikat dalam perkawinan dan hingga sekarang tidak pernah bercerai. Selain itu penggugat juga mengajukan alat bukti tertulis berupa duplikat Kutipan Akta Nikah nomor 51/DN/VIII/2011 atas nama tergugat I dengan tergugat II yang diterbitkan oleh Kantor Urusan Agama Kecamatan Tamalate, Kota Makassar tertanggal 2 Agustus 2011 dan Kutipan Akta Nikah Nomor 408/42/IV/2011 tertanggal 7 April 2011 tersebut sebagai akta otentik yang tidak berkekuatan huku.

Dalam pertimbangan ini, gugatan penggugat diperkuat oleh keterangan dua orang saksi yang menyebutkan bahwa saksi pertama adalah pembantu Pegawai Pencatat Nikah dan mengenal tergugat I dan tergugat II.Sebelumnya saksi tidak pernah mengenal para tergugat begitu pula penggugat. Saksi juga tidak mengetahui bahwa tergugat I mempunyai istri karena menurut keterangan tergugat I adalah seorang duda yang cerai mati.Karena persyaratan nikah telah terpenuhi sesuai aturan perundangundangan sehingga saksi mengawinkan tergugat I dengan tergugat II.Saksi mengetahui bahwa tergugat I dengan tergugat II menikah pada tanggal $18 \mathrm{Mei}$ 2011 di Makassar.Satu bulan setelah 65 pernikahan tersebut, anak tergugat I mendatangi saksi dan menyatakan bahwa saya adalah anak tergugat I dimana ibunya masih hidup (penggugat).

Adapun saksi kedua adalah teman tergugat I yang juga mengenal penggugat namun tidak mengenal tergugat II.Saksi tidak mengenal keluarga tergugat II dan mengetahui kalau ada rencana pernikahan tergugat I dengan tergugat II setelah tiba di rumah tergugat II. Saksi juga tidak mengetahui surat persyaratan nikah dan tidak mengetahui kalau tergugat I adalah berstatus duda. Saksi mengenal penggugat sebagai istri tergugat I, namun sewaktu perkawinan tersebut saksi tidak mengetahui apakah penggugat memberi izin. Saksi mengetahui bahwa tergugat I dan tergugat II menikah pada tanggal 18 Mei 2011 di Makassar karena saksi yang menjadi saksi nikah bersama teman.Pertimbangan lain adalah pernikahannya dilangsungkan di Kantor Urusan Agama Kecamatan Tamalate, Kota Makassar berdasarkan data palsu karena identitas yang diberikan tidak sesuai dengan kenyataannya dimana dalam pernikahan tersebut tergugat I mengaku bahwa tergugat I merupakan seorang duda yang cerai mati oleh istri sebelumnya yang mana diketahui bahwa istri tergugat I masih hidup.

Dalam pertimbangan ini yang terjadi bukan hanya unsur perdata saja, tetapi juga terkait dengan unsur pidana yang mana unsurnya memalsukan identitas diri yang menyebabkan kerugian dari orang lain dan juga negara. Oleh karena alasan dan pertimbangan tersebut maka majelis hakim mengadili bahwa; 1) Mengabulkan gugatan penggugat dengan verstek; 2) Membatalkan perkawinan tergugat I 
dengan tergugat II, yang dilangsungkan di Kantor Urusan Agama Kecamatan Tamalate, Kota Makassar pada tanggal 18 Mei 2011; dan 3) Menyatakan Duplikat Kutipan Akta Nikah, Nomor 51/DN/VIII/2011 tertanggal 2 Agustus 2011 yang dikeluarkan oleh Kantor Urusan Agama Kecamatan Tamalate, Kota Makassar tidak berkekuatan hukum.

Perkawinan yang dilangsungkan oleh tergugat I dan tergugat II yang menyebabkan penggugat mengajukan gugatan pembatalan perkawinan karena tidak adanya izin poligami.Setelah menghadirkan dua orang saksi yang telah memberikan keterangan-keterangan di bawah sumpah dan berdasarkan alat bukti yang diajukan oleh penggugat berupa Duplikat Kutipan Buku Nikah, Nomor 51/DN/VIII/2011.

Perkawinan antara tergugat I dengan tergugat II dinyatakan bahwa Kutipan Akta Nikah 408/42/IV/2011 yang dikeluarkan oleh Kantor Urusan Agama Kecamatan Tamalate, Kota Makassar tidak berkekuatan hukum. Oleh karena itu pembatalan perkawinan ini berdasarkan hasil wawancara dari Mahmudin selaku Hakim Pengadilan Agama Makassar adalah pembatalan perkawinan berdasar kepada kewenangannya sesuai dengan Undang-Undang yang berlaku, dimana kita ketahui bahwa kewenangan 67 tersebut tergantung pada kasus dan apa yang menjadi dasar adanya pembatalan perkawinan tersebut (Tanggal 20 Maret 2013).

Lebih lanjut Mahmudin menegaskan bahwa pemalsuan identitas dari tergugat I sebenarnya bukan menjadi tanggungjawab dari Pengadilan Agama dikarenakan hal tersebut merupakan kewenangan dari pengadilan yang mengatur tentang tindak pidana. Terhadap kontrol dalam pemalsuan identitas, Mahmudin mengatakan bahwa Pengadilan Agama tidak berwewenang selama tidak ada yang membantah hal tersebut karena Pengadilan Agama tidak berkekuatan hukum untuk menentukan benar tidaknya identitas yang diberikan, namun jika terjadi hal tersebut Pengadilan Agama menyerahkan langsung kepada Pengadilan Tata Usaha Negara untuk menentukan benar tidaknya identitas pihak yang terkait.

Mahmudin hanya menegaskan bahwa jika memang seorang ingin melakukan perkawinan poligami sebaiknya pihak tersebut harus memiliki izin atau setidaknya diketahui oleh istri-istri sebelumnya, serta menyertakan suratsurat keterangan yang diperlukan dalam perkawinan poligami.

Yang juga menjadi pertimbangan hakim dalam memutus perkara ini adalah karena tidak adanya izin dari Pengadilan Agama dan juga izin dari istri yang bersangkutan baik secara tertulis maupun lisan. Dalam perkara ini juga, Kantor Urusan Agama Kecamatan Tamalate dinyatakan turut 68 sebagai tergugat bukan semata-mata bahwa KUA tersebut sepenuhnya bersalah melainkan Kantor Urusan Agama Kecamatan Tamalate dilibatkan karena KUA tersebut sebagai pihak yang mengawinkan tergugat I dengan tergugat II. Dalam hal ini, Pengadilan Agama hanya ingin meminta 
informasi terkait pembatalan perkawinan antara tergugat I dengan tergugat II.

\section{KESIMPULAN}

Berdasarkan hasil penelitian dan pembahasan yang telah di uraikan diatas, maka penulis dapat menarik kesimpulan sebagai berikut:

1. Pertimbangan hakim dalam memutus perkara putusan Nomor : 1098/Pdt.G/2011/PA.Mks telah sesuai karena berdasarkan penjabaran keterangan para saksi dan alat bukti serta adanya pertimbanganpertimbangan yuridis serta memperhatikan Undang-Undang Perkawinan Nomor 1 Tahun 1974 dan Kompilasi Hukum Islam yang diperkuat dengan keyakinan hakim. Selain itu pertimbangan hakim yang menyebabkan terjadinya pembatalan perkawinan dari Pengadilan Agama adalah karena perkawinan tersebut tidak memenuhi syarat-syarat perkawinan, adana pemalsuan identitas dari calon mempelai, kurang telitinya administrasi calon suami istri dan kurangnya pemahaman masyarakat terhadap ketentuan Undang-Undang Perkawinan Nomor 1 Tahun 1974 dan Kompilasi Hukum Islam.

2. Akibat hukum terhadap pembatalan perkawinan yaitu harus dipenuhinya masa iddah dan terhadap suami istri diantara keduanya dianggap tidak pernah terjadi perkawinan. Jadi putusan pengadilan berlaku surut terhadap perkawinan yang telah dibatalkan, sesuai dengan Pasal 28 Undang-Undang Perkawinan Nomor 1 Tahun 1974 bahwa batalnya suatu perkawinan dimulai setelah keputusan pengadilan mempunyai kekuatan hukum yang tetap dan berlaku sejak berlangsungnya perkawinan.

\section{Saran}

Berdasarkan kesimpulan tersebut di atas, maka penulis mengajukan saran sebagai berikut :

1. Diharapkan adanya kesadaran hukum dari berbagai pihak dalam semua hal, khususnya dalam hubungannya dengan perkawinan. Perkawinan merupakan sesuatu yang suci dan sakral untuk itu, hendaknya perkawinan haruslah dilakukan sesuai dengan agama serta aturan dan hukum yang berlaku di negara sehingga peristiwa pembatalan perkawinan seperti dalam kasus ini tidaklah terulang lagi.

2. Bagi masing-masing calon mempelai sebaiknya saling mengenal lebih jauh lagi status dari masing-masing pihak dan meneliti apakah ada halangan perkawinan baik menurut hukum agama maupun Peraturan Perundangundangan yang berlaku.

\section{REFERENSI}

Manan, H. A. (2008). Masalah Hukum Perdata Islam di Indonesia. Jakarta: Kencana.

Prawirohamidjodjo, R. S. \& Pohan, M (1991). Hukum Orang dan Keluarga. Surabaya: Airlangga University Press. 
Jurnal Pendidikan Kewarganegaraan,

Vol. 4, No. 2, September 2017
Available online at $h t t p: / / o p e n j o u r n a l . u n p a m . a c . i d / i n d e x . p h p / P K n$

Rasyid, H. \& Roihan, A. (2005). Hukum Acara Peradilan Agama. Jakarta: PT Raja Grafindo Persada.

Sarwono. (2012). Hukum Acara Perdata Teori dan Praktik. Jakarta: Sinar Grafika.

Soemiyati. (2007). Hukum Perkawinan Islam dan Undang-Undang Perkawinan. Yogyakarta: Liberty.

Soeroso, R. (2011). Tata Acara dan Proses Persidangan. Jakarta: Sinar Grafika.

Syarifuddin, A. (2011). Hukum Perkawinan Islam di Indonesia, Jakarta: Kencana.

Tutik, T. T. (2008). Hukum Perdata dalam Sistem Hukum Nasional. Jakarta: Kencana. 